\title{
Release and cycling of nutrients between planktonic algae and herbivores ${ }^{1}$
}

\section{John T. Lehman}

Division of Biological Sciences, University of Michigan, Ann Arbor $\downarrow 18109$

\begin{abstract}
Efforts to quantify nutrient release by zooplankton in situ cre usually complicated by simultaneous uptake of the nutrients by phytoplankton. Eithe' separating the animals from their food or severely concentrating the zooplankton assemblc ge before measuring nutrient release introduces biases. Results are reported from experimer ts in which uptake and regeneration of nutrients were measured simultaneously in an intact alga-herbivore assemblage. Short term responses to pcrturbations of both nutrients and zcioplankton were followed and grazing rates as well as the nutrient fluxes quantified. Magni udes of uptake and recycling depend on the nutritional status of the algal cells, with nutrient-deficient cells displaying faster rates of uptake and lower rates of remineralization than $n$ utrient-sufficient cells for both phosphate and ammonia. The recycled nutrients are rapidly sequestered by the algae and contribute substantially to growth rates of the cells.
\end{abstract}

One persistent feature of temperate plankton communities is the progression during spring and summer from a period of principally abiotic control of population growth to a time of strong biotic interactions. Many workers have explained the vernal successes of some species strictly in terms of physical and chemical conditions (e.g. Whipple and Jackson 1899; Pearsall 1932; Hutchinson 1944; Lund et al. 1963), but interpreting population dynamics from the physical and chemical environment alone can prove insufficient after early spring, because biological processes grow in prominence as the season advances. Among the most obvious biotic reactions affecting the phytoplankton community is the selective mortality caused by the size- and species-specific grazing habits of the herbivorous zooplankton (Berman and Richman 1974; Porter 1977; Richman et al. 1977). Another force in the dynamics of these communities is also linked to the abundance and activities of planktonic herbivores, but it is more subtle than the mortality caused by their grazing. Nutrients are regenerated to dissolved pools as a result either of excretion or of breakdown of the incompletely digested re-

\footnotetext{
1 This work was supported by a grant from the Rackham School of Graduate Studies at the University of Michigan.
}

mains of egested algal cells. The liberated nutrients are usually very reactive biologically, and they are available not only to the preferred prey of the herbivores but also to their competitors.

When the nutritional demands of phytoplankton in situ are estimated from primary production data, or from nutrient uptake, one often finds that the cells are using inorganic nutrients at rates far greater than those at which the substances are supplied from external sources (Barlow anc. Bishop 1965; Ganf and Blažka 1974; Lehman 1978). Cycling of nutrients with in the water column must occur, and that raises an important question. Is physiologrical death of the phytoplankton so important (Jassby and Goldman 1974) that autolysis aided by bacterial action can account for most of the recycling (Golterman 1973), or do the zooplankton contribute significantly to the required fluxes? Several factors have combined to make this a particularly refractory issue from a technical point of view. The first is the very rapid rate at which phytoplankton exchange nutrients, especially P, with the water (Rigler 1973; Lean 1973). These are two-way fluxes, and they cannot: be included in the same category with net fluxes resulting from excretion or autolysis of cells because they do not contribute to de novo synthesis of cellular bic mass. In fact, the guiding as- 
sumption in the studies that measure these two-way fluxes is one of virtual steady state for mass influx and efflux, an equilibrium system into which temporary isotopic disequilibrium is introduced. These exchange fluxes introduce the greatest complication when radiotracers are used to measure turnover rates.

When ambient concentrations are measured directly, on the other hand, results are complicated by the fact that measured concentrations represent a balance between rates of nutrient remineralization by the zooplankton and the simultaneous rates of uptake of those same nutrients by phytoplankton. First filtering the algae from the water is not the answer, because animals without food behave differently from well fed ones (Conover and Corner 1968; Takahashi and Ikeda 1975; Mayzaud 1976; Ikeda 1977; Lampert 1978). Similarly, concentrating the zooplankton to obtain easily measurable rates of nutrient excretion could mean that food supplies may be rapidly exhausted, the animals may be damaged, or their physiology, including the rates and forms of excreted substances, may change (Mullin et al. 1975).

I here report efforts to overcome these problems and to quantify the magnitudes of nutrient fluxes from both excretion and egestion by herbivorous zooplankton. The experiments were conducted with laboratory cultures, but they are designed for application in field studies using enclosures with natural plankton.

I thank L. A. Fieber for technical assistance during the study, and R. Peters for helpful comments on the text.

\section{Methods}

Batch cultures of Chlamydomonas reinhardtii were kept at $20^{\circ} \mathrm{C}$ in a $16: 8$ light:dark cycle on modified WC culture medium (Guillard and Lorenzen 1972) with $40 \mathrm{mg} \mathrm{NH}_{4} \mathrm{NO}_{3} \cdot$ liter $^{-1}$ as the nitrogen source and bicarbonate as the only buffer. A stock culture of Daphnia pulex was grown on aged tapwater in a glass aquarium (75 liters) under the same light and temperature regime as the algae and fed periodically with Chlamydomonas collected by centrifugation from batch cultures.

All experiments were conducted in a basal inorganic medium free of $\mathrm{N}$ and $\mathrm{P}$ (subsequently called NOPN medium) prepared with $20 \mathrm{mg} \mathrm{CaCl} \cdot 2 \mathrm{H}_{2} \mathrm{O}, 10 \mathrm{mg}$ $\mathrm{MgSO}_{4}$, and $20 \mathrm{mg} \mathrm{NaHCO}_{3}$ per liter of distilled, deionized water, and with trace metals and vitamins at $1 \%$ of their concentration in WC medium. The Daphnia could live, feed, and reproduce in this medium for at least several weeks when supplied with algae regularly.

Daphnia was collected for the experiments by passing a submerged Plexiglas cylinder fitted at one end with $505-\mu \mathrm{m}$ Nitex netting through the aquarium culture. Captured individuals were pipetted into a smaller cylinder, similarly fitted at one end with Nitex netting, resting inside a beaker filled with NOPN medium. The animals were rinsed by pouring one or more liters of NOPN medium into the inner cylinder, allowing the excess to pass through the netting and to overflow from the beaker. Animals thus rinsed were pipetted into experimental vessels, having remained actively swimming the whole time. At the end of an experiment the animals were collected on preweighed disks of $40-\mu \mathrm{m}$ Nitex netting and dried at $60^{\circ}$ for $24 \mathrm{~h}$, then weighed on a Cahn electrobalance. In some cases the dried animals were scraped from the disks and digested with potassium persulfate (Menzel and Corwin 1965) in an autoclave for $60 \mathrm{~min}$ at $120^{\circ} \mathrm{C}$, and then analyzed for total $\mathrm{P}$ by the acid-molybdate method of Strickland and Parsons (1972). Most of the animals used ranged from 1.7 to $2.2 \mathrm{~mm}$ long excluding the tail spine (although some individuals as small as $1.1 \mathrm{~mm}$ were included), and their average individual dry weight was $20 \mu \mathrm{g}$. Reproductive females generally carried 4 or 5 eggs per clutch, but not all females that were large enough actually bore clutches, indicating that food was potentially limiting to the animals.

Algae were prepared for experiments by centrifuging portions of the batch culture, rinsing and resuspending the cells in NOPN medium, centrifuging them 
once again, and finally suspending them in NOPN medium. Abundances were assessed from microscope counts with either a Sedgwick-Rafter cell or a hemacytometer. When cell volumes were measured as well, 30 cells from each sample were measured with an ocular micrometer at $400 \times$ using the hemacytometer. Volumes were calculated from $4 / 3$ $\pi a^{2} b$, where $b$ was half the maximum length and $a$ was half the width.

Kinetics of nutrient uptake were measured by nutrient-depletion experiments. Rinsed cells were suspended in several liters of NOPN medium $\left(\leqslant 10^{5}\right.$ cells $\left.\cdot \mathrm{ml}^{-1}\right)$ and preincubated for $1 \mathrm{~h}$ with $0.1 \mu \mathrm{M}$ $\mathrm{KH}_{2} \mathrm{PO}_{4}$ or $0.5 \mu \mathrm{M} \mathrm{N}$ as $\left(\mathrm{NH}_{4}\right)_{2} \mathrm{SO}_{4}$. The medium was then mixed and dispensed into several 1-liter Erlenmeyer flasks, and a graduated series of nutrient additions was made to the flasks. For $\mathrm{PO}_{4}$ uptake studies, $\mathrm{NH}_{3}$ was supplied at a ratio to $\mathrm{PO}_{4}$ of $10: 1$ by atoms. For studies of $\mathrm{NH}_{3}$ uptake, $\mathrm{PO}_{4}$ was supplied at $2 \mu \mathrm{M}$, a saturation concentration. Initial samples were filtered through GF/F filters, with subsequent samples filtered at intervals of $15 \mathrm{~min}$ to $2 \mathrm{~h}$, depending on cell numbers and ambient nutrient concentrations. The sampling regime ensured that concentrations of dissolved nutrients changed by $<25 \%$ between samples. Rates of nutrient uptake were calculated from the measured change in concentration per unit time, and the calculated values were assigned to the midpoints of the concentration ranges. Soluble reactive $\mathrm{PO}_{4}$ (SRP) was analyzed as described by Strickland and Parsons (1972); ammonia analyses followed Solórzano (1969). Total dissolved $P$ was determined by persulfate digestion (Menzel and Corwin 1965), followed by neutralization and analysis of the digests for $\mathrm{PO}_{4}$ as described above. Chlorophyll and pheopigments were measured by the method of Lorenzen (1967), using the algae collected on $\mathrm{GF} / \mathrm{F}$ filters. The filters were extracted and shredded in a tissue grinder in $90 \%$ acetone buffered with 1 $\mathrm{mg} \mathrm{MgCO}_{3} \cdot$ liter $^{-1}$ at $-10^{\circ} \mathrm{C}$. The resultant slurry was filtered through a GF/F filter and the absorbance of the filtrate measured over a $4-\mathrm{cm}$ path length. The spectrophotometric equations and calculations for Chl $a$ and pheopigments were standardized against a sample of pure Chl $a$ (Sigma Chemical Co.).

\section{Results}

A few preliminary experiments were conducted to evaluate alternative methods of measuring nutrient release from Daphnia. Animals were removed from laboratory culture, rinsed, and placed in a series of flasks each containing $1,000 \mathrm{ml}$ of the inorganic medium (NOPN). The measured changes in nutrient concentrations in these flasks after either 2 or 20.5 $\mathrm{h}$ are listed in Table 1 , where nutrient release by the animals is expressed in terms of dry weight. Total accumulated $\mathrm{P}$ or $\mathrm{N}$ is greater after $20 \mathrm{~h}$ than after $2 \mathrm{~h}$, but the difference is clearly far less than a factor of 10 . Because the animals were removed from their food at time $=0$, one can infer that rates of nutrient release are greatest when the animals are actively feeding, but quantifying rates of release of nutrients under those conditions can be very difficult. Two experiments that illustrate the problems are shown in Fig. 1. I og-phase Chlamydomonas were suspended in several liters of NOPN medium and dispensed to individual flasks. Rinsed $D$. pulex from laboratory culture were then added in varied numbers to each flask. Substantial accumulation of $P$ and $\mathrm{N}$ occurs only when animals are numerous enough to greatly reduce abundances of algae, shown here as concentrations of Chl $a$. The pattern of nutrient accumulation is distinctly nonlinear with zooplankton abundance (Fig. 1: lower panel) because when the concentrations of algae are decreased by grazing, the overall potential of the algal population to absorb released nutrients necessarily decreases as well. Rates of nutrient uptake by the algae depend on ambient concentrations in the water; at low concentrations rates of uptake per algal cell increase with external levels, thus opposing accumulations from nutrient release by the animals. In short, the fewer algae that remain, the more readily nutrients 
Table 1. Normalized release of dissolved nutrients $\left(\mu \mathrm{mol} \cdot \mathrm{mg}\right.$ dry $\left.\mathrm{wt}^{-1}\right)$ for Daphnia (mg dry wt $\cdot$ liter $^{-1}$ ) removed from food at time $t_{0}$.

\begin{tabular}{ccccc}
\hline \hline Daphnia & $\begin{array}{c}\Delta t \\
(\mathrm{~h})\end{array}$ & $\mathrm{PO}_{4}$ & Diss. $\mathrm{P}$ & $\mathrm{NH}_{3}$ \\
\hline 1.12 & 2 & 0.029 & 0.034 & 0.19 \\
1.32 & 2 & 0.028 & 0.033 & 0.17 \\
0.71 & 20.5 & 0.033 & 0.050 & 0.43 \\
0.89 & 20.5 & 0.063 & 0.079 & 0.42 \\
0.91 & 20.5 & 0.113 & 0.121 & 0.90 \\
1.00 & 20.5 & 0.070 & 0.100 & 0.52 \\
\hline
\end{tabular}

can accumulate in the water. On the other hand, rates of nutrient release by the animals decline when their food supply is diminished. Efforts to assess precisely the magnitudes of recycling fluxes consequently are confounded by the interactions among algal growth, nutrient uptake, grazing, and nutrient release.

Simultaneous measures of uptake and remineralization-One way to overcome this problem is to create experimental conditions that reduce some of the variability, by making use of the nonlinear response of uptake rates to nutrient concentrations. Whether nutrient uptake by phytoplankton is best represented by a rectangular hyperbola (Brown et al. 1978), nutrient uptake and transport systems of algal cells always become saturated when concentrations are high enough. If nutricnt concentrations are adjusted to saturating levels, rates of uptake of nutrients by phytoplankton will be relatively constant and independent of nutrient fluxes from the animals during short periods. Rates of regeneration can then be assessed from net rates of change of nutrient concentrations as functions of zooplankton abundance. The reason for this is that the zooplankton slow the net rate at which nutrients are removed because they contribute dissolved nutrients to the water-nutrients that are simultaneously utilized by the algae. The change in nutrient concentration $(S)$ can thus be described as

$$
\mathrm{d} S / \mathrm{d} t=-u A+c Z
$$

where $u$ is the rate of nutrient uptake per unit algae, and $c$ is the rate of nutrient
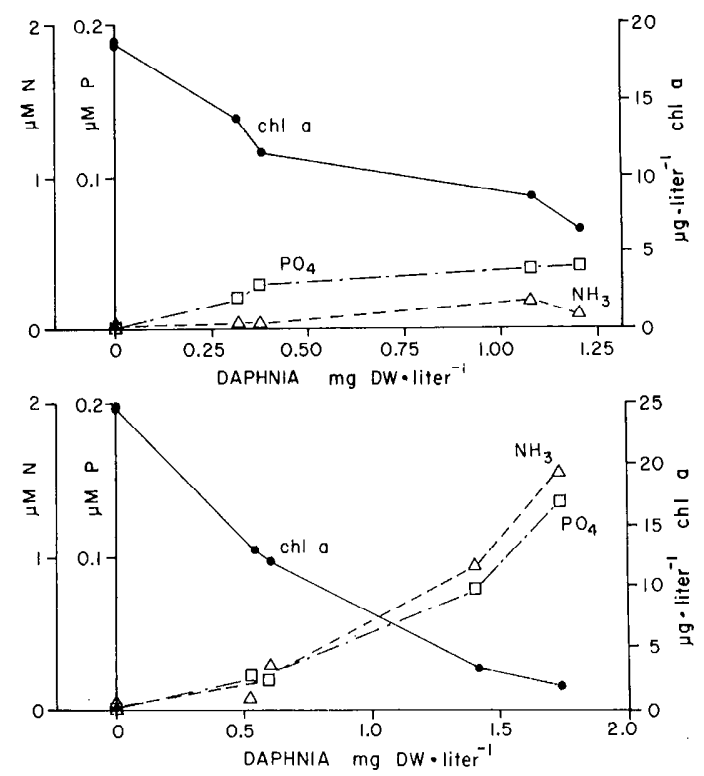

Fig. 1. Net accumulation of $\mathrm{NH}_{3}$ and $\mathrm{PO}_{4}$ in suspensions of Chlamydomonas in presence of Daphnia pulex. Upper panel- $\Delta t=14.5 \mathrm{~h}$, initial Chl $a=18.8 \mu \mathrm{g} \cdot$ liter $^{-1}$; lower panel- $\Delta t=20 \mathrm{~h}$, initial Chl $a=21.9 \mu \mathrm{g} \cdot$ liter $^{-1}$.

release per unit zooplankton. The total biomass of zooplankton $(Z)$ will remain almost constant during the course of a single experiment (several hours to a day), but changes in algal abundance $(A)$ may occur, as

$$
\mathrm{d} A / \mathrm{d} t=r A
$$

where $r$ is the net intrinsic rate of growth or decline-a balance between cell division and grazing losses. When initial nutrient concentrations have been adjusted to a saturating level $(\mathrm{d} u / \mathrm{d} S=0)$, these equations can be integrated to yield

$$
-\Delta S /(\Delta t \cdot \bar{A})=-c Z / \bar{A}+u
$$

where $\bar{A}=\Delta A /(r \cdot \Delta t)$, which can be solved by linear regression on the empirical data to give values for uptake $u$ and nutrient release $c$. Growth rate is computed from $r=\left(\ln A-\ln A_{0}\right) / \Delta t$, by presuming that abundances change exponentially over the experimental interval.

Transformed data from two experiments are plotted in Fig. 2. The vertical axis is $-\Delta S /(\Delta t \cdot \bar{A})$ and the horizontal axis 

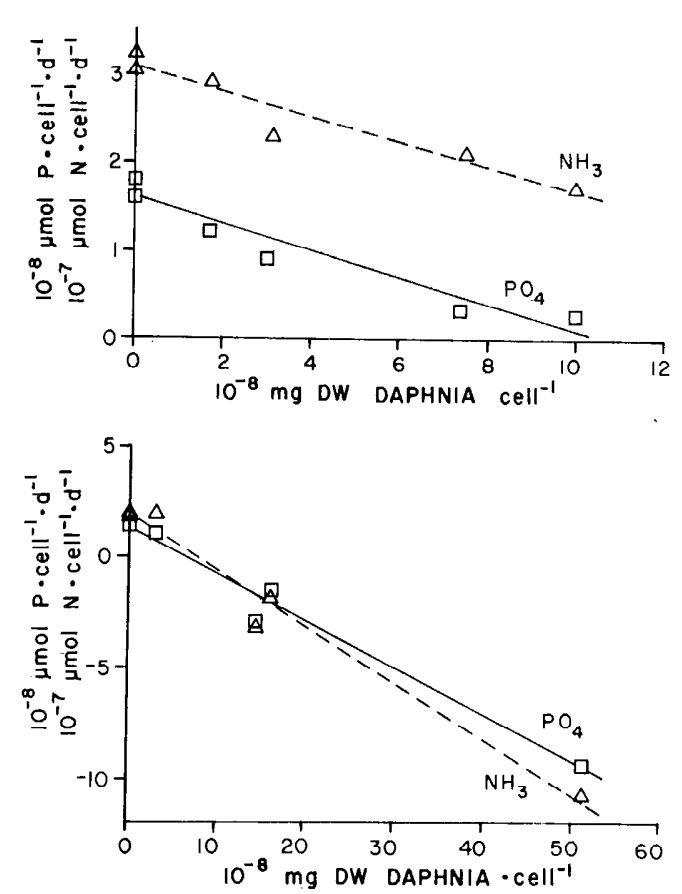

Fig. 2. Data from two experiments with Chlamydomonas and Daphnia pulex illustrating transformations appropriate for measuring uptake and remineralization of nutrients by model described in text. Upper panel-experiment $1, \Delta t=23 \mathrm{~h}$; lower panel-experiment $2, \Delta t=24 \mathrm{~h}$. Slopes and intercepts of regression lines listed in Table 2.

is $Z / \bar{A}$. Studies of the uptake kinetics of $\mathrm{PO}_{4}$ and $\mathrm{NH}_{3}$ by Chlamydomonas had shown that maximal rates of uptake for each nutrient could vary among experiments but that the data always conformed satisfactorily to saturating rectangular hyperbolas (Fig. 3). Concentrations of 15 $\mu \mathrm{M} \mathrm{NH}$ and $2 \mu \mathrm{M} \mathrm{PO}_{4}$ were selected as values high enough to ensure that rates of uptake would not vary with small changes in substrate concentrations (i.e. uptake rates were well on the plateaus of the curves for those values). By adding those concentrations to the experimental flasks initially, my assumption of constant uptake rate required by the mathematical model was valid, and the data could be evaluated within the scheme I have outlined. Rates of maximal nutrient uptake and nutrient remineralization for these experiments are listed in Table 2.

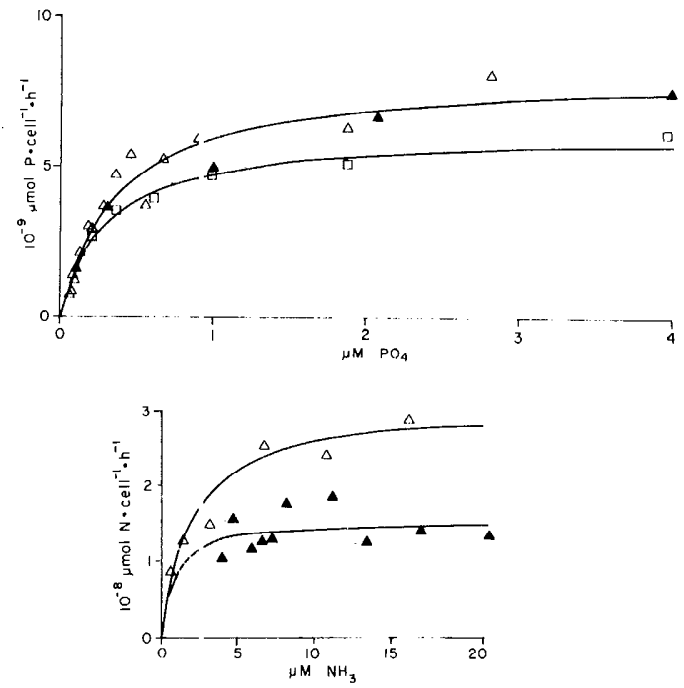

Fig. 3. Kinetics of uptake of $\mathrm{PO}_{4}$ and $\mathrm{NH}_{3}$ by Chlamydomonas. Symbols distinguish different experiments wilh each nutrient. Rectangular hyperbolas fit to data by nonlinear regression. Upper panel- $u_{m}=8.14(\mathrm{SE}=0.39) \times 10^{-9} \mu \mathrm{mol} \mathrm{P}$. cell $^{-1} \cdot \mathrm{h}^{-1}, k_{s}=0.369(\mathrm{SE}=0.049) \mu \mathrm{M} \mathrm{PO}, n=$ $20(\triangle, \Delta)$ and $u_{m}=6.13(\mathrm{SE}=0.28), k_{s}=0.287(\mathrm{SE}=$ $0.050), n=6$ (口). Lower panel-u $u_{m}=3.08$ ( $\mathrm{SE}=$ $0.22) \times 10^{-8} \mu \mathrm{mol} \mathrm{N} \operatorname{cell}^{-1} \cdot \mathrm{h}^{-1}, k_{s}=1.94(\mathrm{SE}=$ $0.49) \mu \mathrm{M} \mathrm{NH}, n=6(\triangle)$ and $u_{m}=1.55(\mathrm{SE}=0.22)$, $k_{s}=0.81(\mathrm{SE}=1.27), n=10(\Delta)$.

For both $\mathrm{N}$ and $\mathrm{P}$, uptake rates were greater but egeneration rates were lower in experiment 1 than in experiment 2 . The differe aces are not statistically valid in all case:; but they suggest that the physiological states of the cells might have a strong effect on flux rates.

Estimates for grazing rates-The manipulations described above can be used to estimate feeding rates for the animals as well as nutrient fluxes. Because cells in all flasks are exposed to identical saturating nutrient regimes, rates of cell division are s.milar among treatments. Differences among treatments with respect to algal abindance are thus traceable to differences in grazing losses. If net intrinsic growth rates $\left(r, \mathrm{~d}^{-1}\right)$ are plotted vs. abundance of animals (mg dry wt $\cdot$ liter $^{-1}$ ), the slope o:: the resulting line has units: liters $\cdot m g d r y w^{-1} \cdot d^{-1}$, and is the mean filtering rate (Fig. 4). We consequently obtain feed ng rates that can be weighed 
Table 2. Rates of uptake $\left(10^{-8} \mu \mathrm{mol} \cdot \mathrm{cell}^{-1} \cdot \mathrm{d}^{-1}\right)$ and regeneration $\left(\mu \mathrm{mol} \cdot \mathrm{mg}\right.$ dry $\left.\mathrm{wt}^{-1} \cdot \mathrm{d}^{-1}\right)$ of $\mathrm{N}$ and P calculated from data plotted in Fig. 2.

\begin{tabular}{ccc}
\hline & Uptake (SE) & Regeneration (SE) \\
\hline $\mathrm{PO}_{4}$ & & \\
Exp 1 & $1.56(0.12)$ & $0.145(0.024)$ \\
Exp 2 & $1.25(0.38)$ & $0.208(0.017)$ \\
$\mathrm{NH}_{3}$ & & \\
Exp 1 & $31.1(1.6)$ & $1.44(0.30)$ \\
Exp 2 & $19.9(4.4)$ & $2.54(0.19)$ \\
\hline
\end{tabular}

against the rates of nutrient remineralization calculated from the same experiment.

Cellular nutrients and flux rates-To investigate the phenomenon mentioned in regard to Table 2 (the influence of cellular nutrient status on flux rates), I took two sets of cells from the same batch culture and preincubated them for $23 \mathrm{~h}$ either in NOPN medium without any added $\mathrm{N}$ or $\mathrm{P}$ (nutrient deficient) or in NOPN medium with $2 \mu \mathrm{M} \mathrm{PO}_{4}$ and 15 $\mu \mathrm{M} \mathrm{NH} \mathrm{NH}_{3}$ added (nutrient sufficient). Analyses showed that the nutrient-deficient cells contained $6.59 \times 10^{-9} \mu \mathrm{mol}$ $\mathrm{P} \cdot \operatorname{cell}^{-1}\left(1.60 \times 10^{-10} \mu \mathrm{mol} \mathrm{P} \cdot \mu \mathrm{m}^{-3}\right)$ and $2.71 \times 10^{-7} \mu \mathrm{g}$ Chl $a \cdot$ cell $^{-1}\left(6.59 \times 10^{-9}\right.$ $\mu \mathrm{g}$ Chl $a \cdot \mu \mathrm{m}^{-3}$ ) whereas nutrient-sufficient cells contained $2.92 \times 10^{-8} \mu \mathrm{mol}$ $\mathrm{P} \cdot \operatorname{cell}^{-1}\left(3.69 \times 10^{-10} \mu \mathrm{mol} \mathrm{P} \cdot \mu \mathrm{m}^{-3}\right)$ and $8.56 \times 10^{-7} \mu \mathrm{g}$ Chl $a \cdot$ cell $^{-1}\left(1.08 \times 10^{-8}\right.$ $\left.\mu \mathrm{g} \mathrm{Chl} a \cdot \mu \mathrm{m}^{-3}\right)$. Because there were differences in cell size between the groups, further comparisons are based on cell volumes.

Both groups of cells were then treated in the same way: $2 \mu \mathrm{M} \mathrm{PO}_{4}$ and $15 \mu \mathrm{M}$ $\mathrm{NH}_{3}$ were added to the nutrient-deficient cells, and concentrations in the nutrientsufficient culture, which had fallen to 1.6 $\mu \mathrm{M} \mathrm{PO}_{4}$ and $8.5 \mu \mathrm{M} \mathrm{NH}{ }_{3}$ at the end of preconditioning, were readjusted to their initial values. Finally both groups of cells were dispensed to a series of $1,000-\mathrm{ml}$ flasks and rinsed zooplankton added to some members of the series. The data after $17 \mathrm{~h}$ are listed in Table 3 and the transformed values plotted in Fig. 5 for $\mathrm{PO}_{4}$, total dissolved $\mathrm{P}$, and $\mathrm{NI}_{3}$; calculated rates of uptake and regeneration are

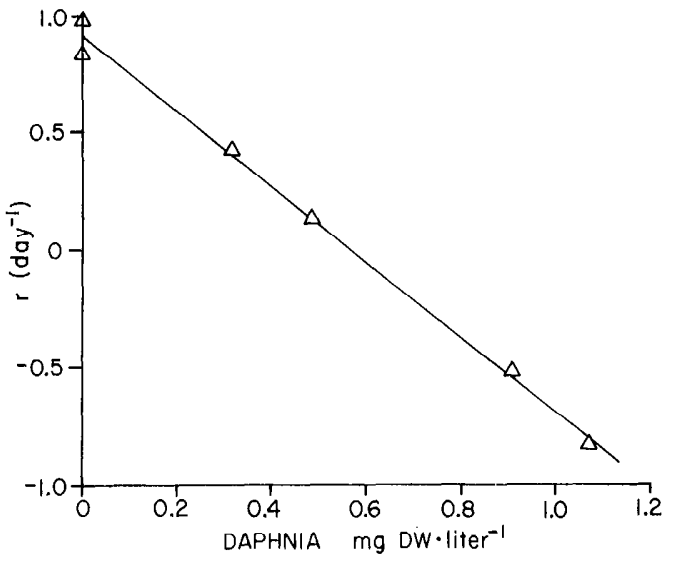

Fig. 4. Net intrinsic growth rates computed from cell counts of Chlamydomonas at a series of abundances of Daphnia (Exp 1 from Fig. 2). Slope of regression line gives mean filtering rate: $1.60(\mathrm{SE}=$ 0.06 ) liters $\cdot \mathrm{mg}$ dry wt Daphnia ${ }^{-1} \cdot \mathrm{d}^{1}, r^{2}=0.994$.

listed in Table 4. Rates of nutrient remineralization have been tabulated both as functions of Daphnia dry weight and as functions of the total $\mathrm{P}$ contents of the animals. Analyses of covariance suggest that the nutrient-deficient cells responded differently from the nutrient-sufficient cells with respect to all three nutrient cat-

Table 3. Abundance of Daphnia (Z, mg dry wt.litcr $\left.{ }^{-1}\right)$, mean abundance of Chlamydomonas $\left(\bar{A}, 10^{8} \mu \mathrm{m}^{3} \cdot\right.$ liter $\left.^{-1}\right)$, and changes in nutrient concentration during an experiment designed to measure rates of nutrient uptake and regeneration simultaneously (see Fig. 5).

\begin{tabular}{|c|c|c|c|c|}
\hline \multirow[b]{2}{*}{$Z$} & \multirow[b]{2}{*}{$\vec{A}$} & \multicolumn{3}{|c|}{$-\Delta S / \Delta t\left\langle\mu \mathrm{M} \cdot \mathrm{h}^{-1}\right)$} \\
\hline & & $\mathrm{PO}_{4}$ & Diss. P & $\mathrm{NH}_{3}$ \\
\hline \multicolumn{5}{|c|}{ Nutrient-deficient cells } \\
\hline 0 & 13.68 & 0.0482 & 0.0500 & 0.378 \\
\hline 0.41 & 9.36 & 0.0309 & 0.0315 & 0.242 \\
\hline 0.71 & 8.21 & 0.0258 & 0.0205 & 0.187 \\
\hline 0.81 & 6.60 & 0.0211 & 0.0177 & 0.163 \\
\hline 1.96 & 4.47 & 0.0057 & 0.0040 & 0.040 \\
\hline 2.11 & 4.65 & 0.0064 & 0.0035 & 0.063 \\
\hline \multicolumn{5}{|c|}{ Nutrient-sufficient cells } \\
\hline 0 & 21.76 & 0.0306 & 0.0311 & 0.340 \\
\hline 0.80 & 8.43 & 0.0163 & 0.0090 & 0.185 \\
\hline 1.58 & 9.12 & 0.0078 & -0.0028 & 0.071 \\
\hline 2.37 & 5.89 & -0.0072 & -0.0154 & -0.067 \\
\hline 2.74 & 4.97 & -0.0099 & -0.0170 & -0.117 \\
\hline 3.10 & 10.03 & -0.0094 & -0.0188 & -0.114 \\
\hline
\end{tabular}




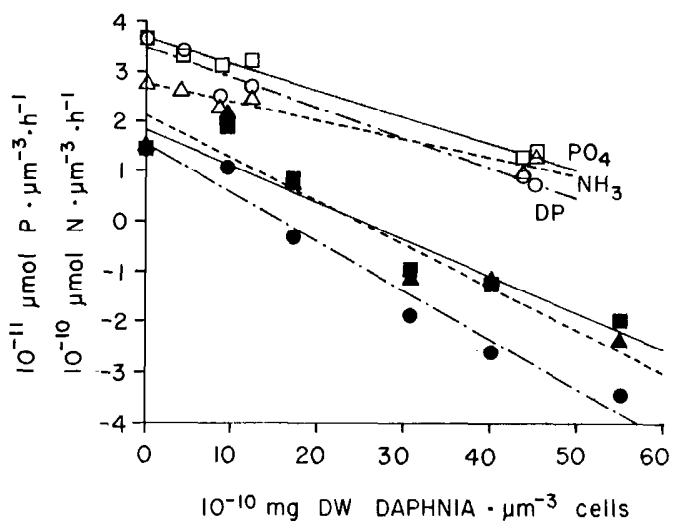

Fig. 5. Effect of nutrient status of algal cells on measured rates of uptake and remineralization. Open symbols-nutrient-deficient cells; solid symbols-nutrient-sufficient cells. Transformed data are plotted for $\mathrm{PO}_{4}$ (squares), $\mathrm{NH}_{3}$ (triangles), and total dissolved $\mathrm{P}$ (circles). Slopes and intercepts of regression lines listed in Table 3.

egories $(P<0.0006$ in all cases). This was due to differences in both uptake rates and rates of nutrient remineralization between treatments (Table 4). The differences are valid at the 0.05 probability level for all cases except uptake of $\mathrm{NH}_{3}$ $(P<0.25)$ and remineralization of $\mathrm{PO}_{4}$ $(P<0.1)$. Filtering rates calculated from the data in Fig. 6 were indistinguishable for the two groups of cells and so were mean ingestion rates calculated from filtering rates and mean cell abundances $(P>0.5)$.

Table 4. Rates of uptake and regeneration of $\mathrm{N}$ and $\mathrm{P}$ calculated from data plotted in Fig. 5. Rates of regeneration normalized both to dry weights and to $\mathbf{P}$ contents of Daphnia. ND-nutrient-deficient cells; NS-nutrient-sufficient cells.

\begin{tabular}{|c|c|c|c|}
\hline & $\mathrm{NH}_{3}(\mathrm{SE})$ & $\mathrm{PO}_{4}(\mathrm{SE})$ & Diss. P (SE) \\
\hline \multicolumn{4}{|c|}{ Uptake $\left(10^{-11} \mu \mathrm{mol} \cdot \mu \mathrm{m}^{-3} \cdot \mathbf{h}^{-1}\right)$} \\
\hline ND & $27.46(1.25)$ & $3.59(0.08)$ & $3.45(0.15)$ \\
\hline NS & $20.92(4.30)$ & $1.90(0.38)$ & $1.49(0.27)$ \\
\hline \multicolumn{4}{|c|}{ Regeneration $\left(10^{-3} \mu \mathrm{mol} \cdot \mathrm{mg}\right.$ dry $\left.\mathrm{wt}^{-1} \cdot \mathrm{h}^{-1}\right)$} \\
\hline ND & $35.94(4.70)$ & $5.02(0.30)$ & $5.97(0.57)$ \\
\hline NS & $82.72(13.58)$ & $7.42(1.19)$ & $9.56(0.86)$ \\
\hline \multicolumn{4}{|c|}{ Regeneration $\left(10^{-2} \mu \mathrm{mol} \cdot \mu \mathrm{mol}\right.$ Daphnia $\left.-\mathrm{P}^{-1} \cdot \mathrm{h}^{-1}\right)$} \\
\hline ND & $8.92(1.19)$ & $1.24(0.10)$ & $1.48(0.14)$ \\
\hline NS & $21.76(4.26)$ & $1.95(0.38)$ & $2.54(0.30)$ \\
\hline
\end{tabular}

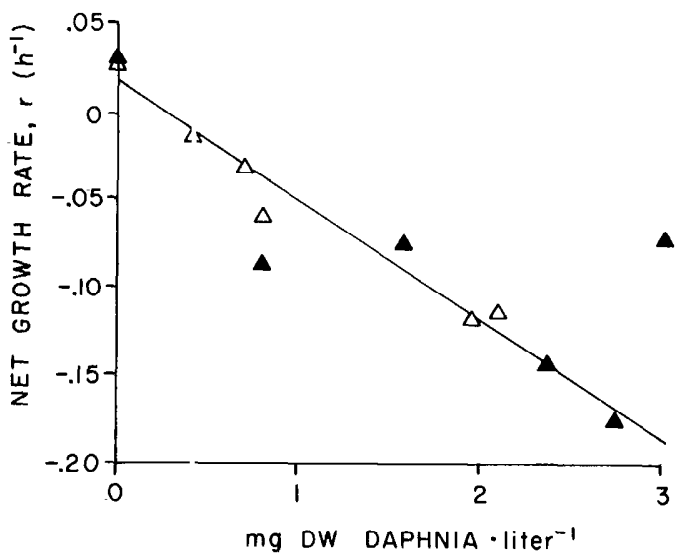

Fig. 6. Net intrinsic growth rates computed from total cell volumes for experiment shown in Fig. 5. $\triangle$-Nutrient-d eficient cells; $\Delta-$ nutrient-sufficient cells. An outly'ing point at $3 \mathrm{mg}$ dry wt $\cdot$ liter $^{-1}$ was omitted from regression. Mean filtering rate $=0.067$ $(\mathrm{SE}=0.007)$ liters $\cdot \mathrm{mg}$ dry wt Daphnia ${ }^{-1} \cdot \mathrm{h}^{-1}, r^{2}=$ 0.933 .

The measured differences in flux rates probably reflect the differences in nutrient contents of the two groups of cells at the start of the experiment. The nutrient-deficient cells have greater maximal rates of nutrient uptake and result in lower remineralization fluxes per unit volume consumed. Because the fluxes are measured in a saturating nutrient regime, the nutrient-deficient cells become progressively less nutrient deficient as the experiment proceeds. By the end of incubation, in fact, only marginal differences remcined between the two groups of cells: $5 .^{\prime}+44 \times 10^{-10}(\mathrm{SE}=0.70, n=6)$ $\mu \mathrm{mol} \mathrm{P} \cdot \mu \mathrm{m}^{-3}$ and $0.93 \times 10^{-8}(\mathrm{SE}=0.06$, $n=6) \mu \mathrm{g} \mathrm{Chl} a \cdot \mu \mathrm{m}^{-3}$ for the nutrientdeficient group compared with $8.12 \times$ $10^{-10}(\mathrm{SE}==2.52, n=6)$ and $1.20 \times 10^{-8}$ ( $\mathrm{SE}=0.12, n=6$ ) for the nutrient-sufficient group. The changes underscore the need for fairly short incubations in these experimen:s.

Enhanced rates of cellular production-Although we can measure rates of nutrient release from zooplankton in these experiments and can infer that the released nutrients are simultaneously absorbed by the algae, it still must be shown tha: the tight cycling among nutrients, algae, and zooplankton results in 
markedly enhanced production rates for the algae. Chlamydomonas was harvested from batch culture and suspended in NOPN medium for $24 \mathrm{~h}$ to make the cells partially nutrient deficient. The medium was dispensed to a series of six flasks and Daphnia was added to four members of the series. After $19 \mathrm{~h}$, the animals were filtered off, samples were taken for nutrients and cell counts, and the remaining culture was incubated for $24 \mathrm{~h}$ more. Net growth rates of the cells are plotted in Fig. 7 during both the first (day 1) and second (day 2) intervals against abundances of Daphnia in the vessels during day 1. Unlike the plots in Figs. 4 and 6 these data do not describe a linear relation over the full range of zooplankton abundances; indeed, there is good reason to suspect that rates of algal growth differ among the treatments. After the animals have been removed, division rates vary with the abundances of Daphnia originally present. The increased growth rates of cells exposed to the higher abundances of animals probably reflect their improved nutrient status; analyses showed that they contained higher cell quotas of $\mathrm{P}$ at the end of day 1 than did cells exposed to few or no zooplankton (Fig. 7: lower panel). Nonetheless, there were virtually no measurable differences among treatments in concentrations of $\mathrm{PO}_{4}$ and $\mathrm{NH}_{3}$ after day 1. Concentrations were $<0.02 \mu \mathrm{M} \mathrm{PO}_{4}$ and $<0.4 \mu \mathrm{M} \mathrm{NH}$ in all cases.

\section{Discussion}

The motive for this study was to measure not just excretion rates but also fluxes resulting from other activities of herbivorous zooplankton that could lead to rapid cycling rates for $\mathrm{P}$ and $\mathrm{N}$ in nature. Rates of nutrient release through excretion and the forms of the excreted nutrients have been carefully studied by many previous investigators. Previous work has shown that for Daphnia spp., $\mathrm{PO}_{4}$ (Peters and Lean 1973) and $\mathrm{NH}_{3}$ (Jacobsen and Comita 1976) are the predominant released forms of $P$ and $N$. Abundant evidence from other sources suggests that the same chemical species
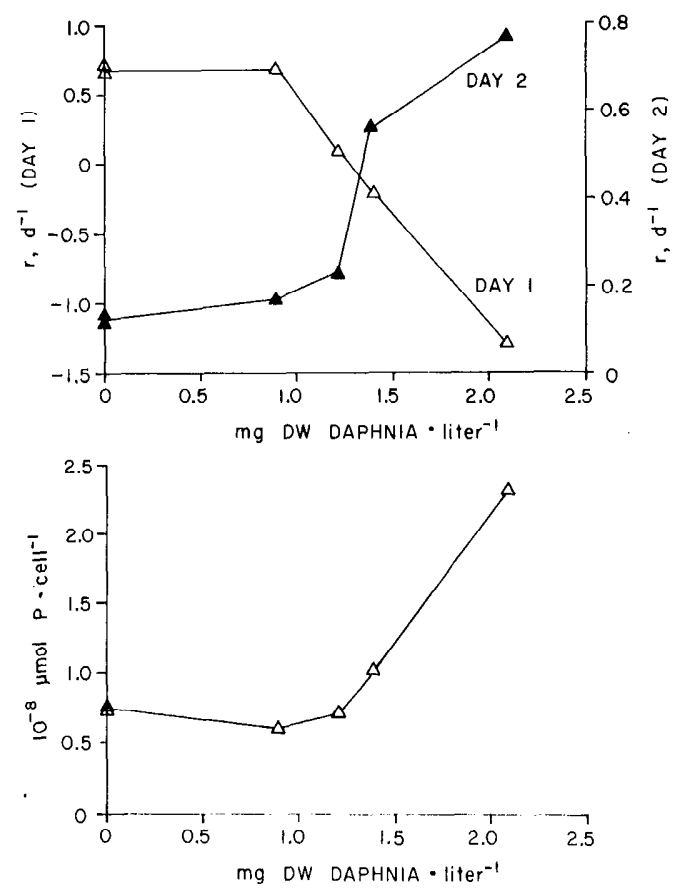

Fig. 7. Upper panel-net intrinsic growth rates of Chlamydomonas at a series of grazer abundances $(\triangle)$ and growth rates achieved after grazers were removed $(\boldsymbol{\Delta})$. Lower panel-cellular $\mathbf{P}$ quotas for Chlamydomonas at end of day 1.

are the main release products of marine copepods as well (Conover and Corner 1968; Butler et al. 1969; Corner and Newell 1967; Jawed 1973). Most of the painstaking measurements have been made with animals rinsed and separated from their food source (e.g. LaRow et al. 1975; LaRow and McNaught 1978). Even if the behavior of the animals were unaffected by these manipulations, the measured fluxes could nonetheless be only a fraction of total rates of remineralization because fluxes from egestion as well as breakage and loss at the mouthparts (Dagg 1976; Lampert 1978) are omitted.

Takahashi and Ikeda (1975) recognized the necessity of keeping the zooplankton well fed during measurements of nutrient release, but their approach was considerably different from mine. They measured rates of uptake by the algae at a range of nutrient concentrations to con- 
struct representative uptake kinetics. They then used measurements of ambient nutrient concentrations in mixtures of algae and zooplankton to compute magnitudes of nutrient release. That procedure was unsatisfactory for my work partly because the uptake characteristics of the algae can vary significantly among experiments, but more importantly because flux rates differ among treatments even when measured ambient concentrations of dissolved nutrients are indistinguishable (cf. Fig. 7). The reason, of course, is that released nutrients do not accumulate in the water; they are swiftly sequestered by the algae and used to enhance their growth. If cycling fluxes are intense, less algal biomass is needed to maintain a given level of productivity. In Fig. 7, the cells which were dividing most rapidly were doing so in the presence of herbivores that cropped the new cells as fast as or faster than they were produced.

Despite low average concentrations of dissolved nutrients, algae may sometimes be dividing at rates close to their physiological maximum, fueled by the rapid biotic cycling of $\mathrm{P}$ and $\mathrm{N}$ (Goldman et al. 1979). There are basically two mechanisms by which this can happen. On the one hand, uptake rates at low substrate concentrations may be much greater than expected by extrapolating down from rates at high concentrations. Brown et al. (1978) have suggested that this may be the case for uptake of phosphate, because rates of turnover for that nutrient are much faster at low ambient concentrations than predicted from data at high concentrations and simple MichaelisMenten kinetics. On the other hand, the scheme might be precisely the one that Goldman et al. (1979) envisaged, with algae encountering very heterogeneous microenvironments, some of which are greatly enriched with nutrients owing to remineralization events. If nutrients are rapidly absorbed by the cells in these episodic and spatially disjoint patches and subsequently used for growth, mean ambient concentrations would indeed remain low and yet be perfectly consonant with rapid cellular division rates. If one can safely assert that zooplankton are dominant agents of nutrient release at some times or places, then this scheme becomes all the more plausible.

The magnitudes of nutrient remineralization by the Daphnia in my study are particularly striking when turnover rates of $P$ are expressed in terms of the $P$ content of the animal (Table 4). Measurements of dissolved $\mathrm{P}$ showed that a mass equivalent to between 1.5 and $2.5 \%$ of the herbivcres' $P$ content was recycled every hour, meaning that between 35 and $60 \%$ of the total herbivore $\mathrm{P}$ is turned over each day. This is not the structural $P$ comprisirig the animals' bodies that is turned over; rather it is egested material and excrete $\mathrm{A}$ P. By analogy to the metabolism of $\mathrm{C}$, a lot of the excreted $\mathrm{P}$ probably results from freshly assimilated material that enters a labile and swiftly metabolized pool and of which only a fraction becomes part of the structural tissue of the organism (Lampert 1975). Peters and Rigler (1973) interpreted their measured rites of radiophosphorus turnover in Daphnia to mean exactly that. The fractions of the total release which are inorganic can be estimated from the relative maynitudes of SRP and dissolved $P$ in Table 4 . For animals feeding on nutrient-deficient cells, 5.02/5.97 $=84.1 \%$ of the flux was due to SRP, and for animals fed vith nutrient-sufficient cells, the value was $7.42 / 9.56=77.6 \%$. Most of this reactive $\mathrm{P}$ is probably orthophosphate (Peters and Lean 1973). The proportion of organic $\mathrm{P}$ measured here is slightly higher than Peters and Lean found, pro oably because my measurements inclıde fluxes from egestion and cell breakage. The rate of release of organic $\mathrm{P}$, and also the fraction of total release which is organic, was greater for animals feeding on nutrient-sufficient cells than for those feeding on nutrientdeficient ones.

One of the most careful studies to date of phosphcrus release by Daphnia is the radiotracer work of Peters and Rigler (1973). The:y measured the rate of release of radiophosphorus from labeled animals 
suspended in unlabeled food, presuming that the tracer release was a measure of excretion. The rates they measured for several Daphnia species are severalfold higher than the measurements I report here. Release rates measured by Peters (1975) for natural assemblages are likewise generally greater than my values. These differences are not strictly related to the $\mathrm{P}$ contents of the animals, because Peters and Rigler (1973) reported $18.0 \mu \mathrm{g}$ $\mathrm{P} \cdot \mathrm{mg}$ dry $\mathrm{wt}^{-1}$ for natural plankton whereas I found D. pulex to have $12.5 \mu \mathrm{g}$ $\mathrm{P} \cdot \mathrm{mg}$ dry $\mathrm{wt}^{-1}=0.404(\mathrm{SE}=0.014) \mu \mathrm{mol}$ $\mathrm{P} \cdot \mathrm{mg}$ dry $\mathrm{wt}^{-1}(n=56)$. The Daphnia used in my study weighed somewhat less than what others have reported for individuals of similar size (e.g. Bottrell et al. 1976), so my animals may have been underfed. Nonetheless the release rates that I measured were still lower than Peters found for starved animals, and these animals definitely were not starved. The method used by Peters and Rigler (1973) and Peters (1975) relies on extrapolating to time zero from exponentially decreasing rates of tracer release from animal into solution. Some uncertainty must exist over how much of this tracer release is proportional to net excretion, and how much represents isotope equilibrium with a small exchangeable pool of $P$ in the animals, analogous to the rapid exchange rates known between algae and the solution (e.g. Lean and Nalewajko 1976). This reasoning may help explain why Peters and Rigler found that the rates of excretion estimated by their technique exceeded the estimates based on ingestion rates and assimilation efficiencies from some of their cxperiments.

Alternatively, we must consider the possibility that my measurements are underestimates of true mass flux from the animals. Elements of the model presented in Eq. 1-3 could be invalidated by the experimental design. Rates both of uptake and nutrient per unit algae $(u)$ and of nutrient release per unit zooplankton $(c)$ are explicitly presumed to be independent of algal abundance within a single expcriment. By the usc of elevated concentrations of dissolved nutrients, up- take rates were saturated and the first condition was met. Rates of nutrient release by the animals, on the other hand, ought to be tied to feeding rates (e.g. Peters and Rigler 1973). We might suspect that a constant fraction of the food consumed by zooplankton would be released to dissolved pools, so that any changes in grazing behavior would be immediately mirrored in the release rates. My data should be most sensitive to this effect for the following reason: plots like those in Figs. 4 and 6 could be constructed only because algal abundances used in this study were at or below the "incipient limiting concentration" for D. pulex (cf. Geller 1975), meaning that filtering rate was independent of food abundance. Because filtering rate was constant between treatments, ingestion rate (= filtering rate $\times$ algal abundance) did vary with changes in cell numbers during each experiment. This means that for treatments with high abundances of zooplankton in which algal numbers declined with time, rates of ingestion per animal and thus, perhaps, rates of nutrient release per animal, must have decreased with time also. Any marked expression of this effect in the data would force us to reject the notion of treating release rate $c$ as a constant within a single experiment and to treat it instead as a function of filtering rate and algal abundance. Appropriately phrased, the question is not whether nutrient release depends ultimately on feeding rates of the animals, which we know it must, but rather whether the rate of nutrient release within a single experiment deviates systematically from constant value. This is testable.

If rates of nutrient release per animal declined measurably with decreases in mean algal abundances in these experiments, the transformed data plotted in Figs. 2 and 5 would be concave upward, not linear. In fact, some evidence for this concavity is apparent from plots of $\mathrm{PO}_{4}$ in experiment 1 (Fig. 2: upper panel) and of dissolved $\mathrm{P}$ for nutrient-sufficient cells (Fig. 5), but residual analyses suggest no reason to think that overall the plots are really nonlinear for any nutrient. In other 
words, rates of nutrient release by the zooplankton apparently do not change greatly enough within the constraints of a single experiment (i.e. within the suite of measurements made at a series of zooplankton abundances) to warrant treating them as anything but constants for that experiment. This means that the model assumption of constant $c$ (nutrient release per unit zooplankton) is satisfied, and no bias of interpretations is likely on that account. It does not rule out the possibility that experiments conducted at widely different cell densities would lead to different measurements for rates of nutrient cycling, but that point was not investigated in this study. The differences in nutrient release measured between nutricnt-sufficient and nutrientdeficient cells (Table 4 ) were strictly valid, therefore, only because mean rates of ingestion of cell biomass were indistinguishable between the two series: 5.9 $(\mathrm{SE}=1.7) \times 10^{7} \mu \mathrm{m}^{3} \cdot \mathrm{mg}$ dry $\mathrm{wt}^{-1} \cdot \mathrm{h}^{-1} \mathrm{vs}$. $6.1(\mathrm{SE}=1.3)$.

Because construction of Eq. 3 involved division of all terms by $\bar{A}$, spurious autocorrelation effects could potentially be introduced among the transformed data. The linear plots in Figs. 2 and 5 thus might be the results of statistical artifacts, rather than of the biological mechanisms I proposed. The easiest way to discount this possibility is to rewrite Eq. 3 as

$$
\Delta S / \Delta t+u \bar{A}=c Z
$$

and to regress $Z$ against $(\Delta S / \Delta t+u \bar{A})$. Thus free of potential autocorrelation the relation should still be linear. The necessary data are listed in Table 3, taken from the experiment in Fig. 5. Uptake $u$ can be estimated from $-\Delta S /(\Delta t \cdot \bar{A})$ in treatments without zooplankton. Treated this way, the data yield linear correlation coefficients of $0.984,0.931$, and 0.944 for $\mathrm{PO}_{4}$, total dissolved $\mathrm{P}$, and $\mathrm{NH}_{3}$ among nutrient-deficient cells, and 0.930, 0.981, and 0.931 for the same nutrient categories among nutrient-sufficient cells. The slopes are not significantly different from values of $c$ listed in Table 3 , and in most cases they are virtually identical. The advantage of using Eq. 3 is that it provides an important estimate for uptake based on the whole data set, rather than on one or two points alone, and it has direct applicability to field situations where it is not technically feasible to remove all the animals from a water sample without affecting the algae simultaneously (cf. Lehmman 1978, in press).

The perturbation method for measuring uptake, egestion, and excretion may work best w th cladocerans like Daphnia which release uncompacted feces to the water, but ir principle there seems to be no problem with applying the method to other herbiv orous zooplankton. Lehman (1978, in press) reported studies on Lake Washington showing that the approach is applicable to natural mixed assemblages of cladocerans, copepods, and rotifers.

The turnciver rates measured in this study were for a moderately large freshwater crustacean zooplankter-D. pulex. Smaller herbivores have faster metabolic rates per ur it biomass. This means that rotifers and protozoans, for instance, may be respons:ble for daily release rates equivalent $10>35-60 \%$ of their own $\mathrm{P}$ contents-th 1 e range measured for $D . p u$ lex. Rigler (1973) and Peters and Rigler (1973) cited studies which report weightspecific rates of $P$ release to vary with the -0.3 to the -0.9 power of zooplankton body weight. Even using the conservative estimate of -0.3 , a rotifer weighing $0.2 \mu \mathrm{g}$ would be expected to release $\mathrm{P}$ equivalent to more than twice its own body $\mathrm{P}$ con ent each day. If the biomass of small metazoans and protozoans is substantial in zny water mass, the impact could obviously be considerable. Gliwicz (1975, 1976' has reported that rates of primary produstion in two tropical lakes are closely corr əlated to the grazing activities of zooplanltonic herbivores, and I observed that nutrient release by zooplankton can surply a major share of the nutritional requirements of epilimnetic phytoplank on in a temperate lake during summer (Lchman 1978, in press)-an observation corroborated by Devol (1979) for the same lake by independent means. Rapid cycling of nutrients between grazers and alg te promotes high rates of pri- 
mary production and cell division at times when allochthonous inputs and dissolved pools could not support populations for even one full day.

\section{References}

BARlow, J. P., AND J. W. Bishop. 1965. Phosphate regeneration by zooplankton in Cayuga Lake. Limnol. Oceanogr. 10(suppl.): R15-R24.

Benman, M., and S. Richman. 1974. The feeding behavior of Daphnia pulex from Lake Winnebago, Wisconsin. Limnol. Oceanogr. 19: 105109 .

BotTrell, H. H., AND OtHers. 1976. A review of some problems in zooplankton production studies. Norw. J. Zool. 24: 419-456.

Brown, E. J., R. F. Harris, and J. K. KoOnCE. 1978. Kinetics of phosphate uptake by aquatic microorganisms: Deviations from a simple $\mathrm{Mi}$ chaclis-Menten equation. Limnol. Occanogr. 23: 26-34.

Butler, E. I., E. D. Conner, and S. M. MarSHALL. 1969. On the nutrition and metabolism of zooplankton. 6. Feeding efficiency of Calanus in terms of nitrogen and phosphorus. $J$. Mar. Biol. Assoc. UiK. 43: 373-386.

Conover, R. J., AND E. D. Corner. 1968. Respiration and nitrogen excretion by some marine zooplankton in relation to their life cycles. J. Mar. Biol. Assoc. U!K. 48: 49-75.

Corner, E. D., AND B. S. Newell. 1967. On the nutrition and metabolism of zooplankton. 4 . The forms of nitrogen excreted by Calanus. J. Mar. Biol. Assoc. U:K. 47: 113-120.

DAGG, M. J. 1976. Complete carbon and nitrogen budgets for the carnivorous amphipod, Calliopius laeviusculus (Krøyer). Int. Rev. Gesamten Hydrobiol. 61: 297-357.

Devol, A. H. 1979. Zooplankton respiration and its relation to plankton dynamics in two lakes of contrasting trophic state. Limnol. Oceanogr. 24: 893-905.

GANF, G. G., AND P. BlažKa. 1974. Oxygen uptake, ammonia, and phosphate excretion by zooplankton of a shallow equatorial lake (Lake George, Uganda). Limnol. Oceanogr. 19: 313325.

Gellen, W. 1975. Die Nahrungsaufnahme von Daphnia pulex in Abhängigkeit von der Futterkonzentration, der Temperatur, der Körpergröße und dem Hungerzustand der Tiere. Arch. Hydrobiol. Suppl. 48, p. 47-107.

GliwiCz, Z. M. 1975. Effect of zooplankton grazing on photosynthetic activity and composition of phytoplankton. Proc. Int. Assoc. Theor. Appl. Limnol. 19: 1490-1497.

-1976. Plankton photosynthetic activity and its regulation in two neotropical man-made lakes. Pol. Arch. Hydrobiol, 23: 61-93.

Goldman, J. C., J. J. MCCarThy, And D. G. PeavEY. 1979. Growth rate influence on the chem ical composition of phytoplankton in oceanic waters. Nature 279: $210-215$.
Golterman, H. L. 1973. Vertical movement of phosphate in froshwater, p. 509-538. In E. J. Griffith et al. [eds.], Environmental phosphorus handbook. Wiley.

GuillaARD, R. R., AND C. J. LoREnzen. 1972. Yellow-green algae with chlorophyllide $c$. J. Phycol. 8: $10-14$

Hutcinsson, G. E. 1944. Limnological studies in Connecticut. 7. A critical examination of the supposed relationship between phytoplankton periodicity and chemical changes in lake waters. Ecology 25: 3-25.

IKEDA, T. 1977. The effect of laboratory conditions on the extrapolation of experimental measurements to the ecology of marine zooplankton. 4 . Changes in respiration and excretion rates of boreal zooplankton species maintained under fed and starved conditions. Mar. Biol. 41: 241252.

Jacobsen, T. R., And G. W. Comita. 1976. Ammonia-nitrogen excretion in Daphnia pulex. IIydrobiologia 51: 195-200.

JAssBY, A., AND C. R. Goldman. 1974. Loss rates from a lake phytoplankton community. Limnol. Oceanogr. 19: 618-627.

JAWED, M. 1973. Ammonia excretion by zooplankton and its significance to primary production during the summer. Mar. Biol. 23: 115-120.

LAMPERT, W. 1975. A tracer study on the carbon turnover of Daphnia pulex. Proc. Int. Assoc. Theor. Appl. Limnol. 19: 2913-2921.

. 1978. Release of dissolved organic matter by grazing zooplankton. Limnol. Occanogr. 23: 831-834.

LARow, E. J., AND D. C. McNaught. 1978. Systems and organismal aspects of phosphorus remineralization. Hydrobiologia 59: 151-154.

- J. W. WILKInSON, AND K. D. Kumar. 1975. The effect of food concentration and temperature on respiration and excretion in herbivorous zooplankton. Proc. Int. Assoc. Theor. Appl. Limnol. 19: 966-973.

LEAN, D. R. 1973. Phosphorus dynamics in lake water. Science 179: 678-680.

_- and C. Nalewajko. 1976. Phosphate uptake and organic phosphorus excretion by freshwater algae. J. Fish. Res. Bd. Can. 33: 1312-1323.

LEIIMAN, J. T. 1978. Aspects of nutrient dynamics in freshwater communities. Ph.D. thesis, Univ. Washington, Seattle. $180 \mathrm{p}$.

—. In press. Nutrient recycling as an interface between algae and grazers in freshwater communities. Am. Soc. Limnol. Oceanogr. Spec. Symp. 3.

LORENZFN, C. J. 1967. Determination of chlorophyll and pheopigments: Spectrophotometric equations. Limnol. Oceanogr. 12 : 343-346.

Lund, J. W., F. J. Mackfreth, and C. H. MoRTIMER. 1963. Changes in depth and time of certain chemical and physical conditions and of the standing crop of Asterionella formosa IIass. in the north basin of Windermere in 1947. phil. Trans. R. Soc. Lond. Ser. B 246: 255-290. 
Mayzaud, P. 1976. Respiration and nitrogen excretion of zooplankton. 4 . The influence of starvation on the metabolism and the biochemical composition of some species. Mar. Biol. 37: 47-58.

Menzel, D., AND N. CoRwin, 1965. The measurement of total phosphorus in seawater based on the liberation of organically bound fractions by persulfate oxidation. Limnol. Oceanogr. 10: 280-282.

Mullin, M. M., M. J. Perry, E. H. Renger, AND P. M. Evans. 1975. Nutrient regeneration by some oceanic zooplankton: A comparison of methods. Mar. Sci. Commun. 1: 1-13.

Pearsall, W. H. 1932. Phytoplankton in English I akes. 2. The composition of the phytoplankton in relation to dissolved substances. J. Ecol. 20: 241-262.

Peters, R. H. 1975. Phosphorus regeneration by natural populations of limnetic zooplankton. Proc. Int. Assoc. Theor. Appl. Limnol. 19: 273279.

-, AND D. LEAN. 1973. The characterization of soluble phosphorus released by limnetic zooplankton. Limnol. Oceanogr. 18: 270-279.

, AND F. H. Rigler. 1973. Phosphorus release by Daphnia. Limnol. Oceanogr. 18: 821839.
Porter, K. G. 1977. The plant-animal interface in freshwater ecosystems. Am. Sci. 65: 159-170.

Richman, S., ['. R. Heinle, and R. Huff. 1977. Grazing by adult estuarine calanoid copepods of the Cherapeake Bay. Mar. Biol. 42: 69-84.

Rigler, F. H. 1973. A dynamic view of the phosphorus cycle in lakes, p. 539-572. In E. J. Griffith ct al. [cds.], Environmental phosphorus handbook. Wiley.

Solórzano, L. 1969. Determination of ammonia in natural waters by the phenolhypochlorite method. Li nnol. Oceanogr. 14: 799-801.

Strickland, J. D., AND T. R. Parsons. 1972. A practical hitndbook of seawater analyses, 2nd ed. Bull. F: sh. Res. Bd. Can. 167.

TAKAHASHI, M., AND T. IKEDA. 1975. Excretion of ammonia and inorganic phosphorus by $E u$ phausia pacifica and Metridia pacifica at different concentrations of phytoplankton. J. Fish. Res. Bd. Ciın. 32: 2189-2195.

Whipple, G. C., AND D. D. JACKSon. 1899. Asterionella-I $\because \mathrm{s}$ biology, its chemistry, and its effect on water supplies. New England Water Works Asscic. 14: 1.-25.

Submitted: 30 October 1979 Accepted: 28 January 1980 